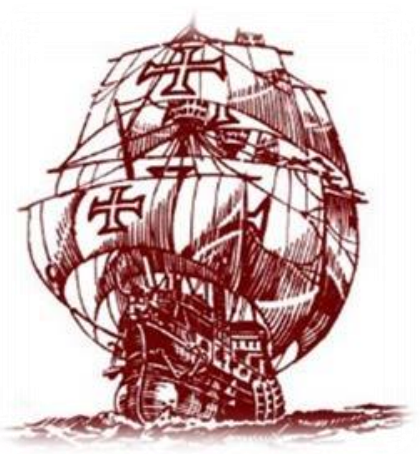

Nau Literária: crítica e teoria de literaturas

www.seer.ufrgs.br/nauliteraria

ISSN 1981-4526 - PPG-LET-UFRGS - Porto Alegre

Vol. 11 N. $01-2015$

100 anos da geração Orpheu

\title{
Recepção da poesia de Roberto Piva de 1960 a 1990
}

\author{
Ricardo Mendes Mattos ${ }^{1}$
}

\begin{abstract}
Resumo: Acompanha-se a recepção da poesia de Roberto Piva no arco temporal de 1960 a 1990, no caleidoscópio que transfigura o poeta ora como "marginal" ou "homossexual-proletário", ora associado à anarquia, à ecologia e ao xamanismo.
\end{abstract}

Palavras-chaves: Roberto Piva; Poesia Contemporânea; Recepção.

Abstract: Analyses the reception of the Roberto Piva's poetry between 1960 and 1990, from the kaleidoscope that transfigures the poet sometimes as "marginal" or "proletarian-gay", sometimes associated with anarchy, ecology and shamanism.

Keywords: Roberto Piva; Brazilian Poetry; Reception Aesthetics.

O ano de 2000 selou a consagração da poesia de Roberto Piva com a reedição de sua obra Paranóia (1963), pelo Instituto Moreira Salles. Logo viria a organização de suas obras reunidas e a aceitação da ideia de que sua poesia precisou de décadas para ser realmente lida. De fato, tomando como exemplo o espaço midiático e a proliferação de entrevistas na edição de 2000, há um contraste evidente com o silêncio em torno de Paranóia em 1963.

Contudo, o silêncio da crítica na década de 1960 esteve lado a lado com o sonoro contágio de Paranóia em meios avançados da criação artística. Da mesma forma, na década de 1970, sua poesia escorreu clandestinamente nos meios jovens da contracultura, com acento na influência sobre a geração da chamada "poesia marginal". Ainda nessa década, Roberto Piva foi lido pelos meios políticos da esquerda e considerado exemplo emblemático da literatura homoerótica pelos movimentos de luta pela diversidade sexual. Durante a década de 1980, os manifestos do poeta deram o que falar no nascente movimento ambientalista brasileiro, além da importante recepção por mais uma jovem geração de escritores vinculados à editora L\&PM. Nesta, o poeta foi considerado "o mais indômito, o mais rebelde e um dos mais inspirados poetas brasileiros das últimas décadas” (L\&PM, 1985), exaltação similar à da revista argentina

\footnotetext{
${ }^{1}$ Doutorando na área de psicologia da arte (USP)
} 
Cerdos \& Peces, que o considerou "o maior poeta brasileiro da atualidade" (Piva, 1989b). Por fim, ainda antes de 2000, os meados de 1990 viram o furor dos jovens transgressores da revista Azougue em torno de Piva, em mais uma ressonância de sua poesia e modo de vida em gerações de novos poetas.

Dessa forma, pode-se afirmar que a poesia de Roberto Piva contou com forte recepção em seu contexto de produção, inclusive com constante contágio entre gerações de jovens poetas que reverberaram toda sua verve subversiva. Eis o intento deste estudo: acompanhar a recepção da poesia de Roberto Piva no arco temporal das décadas de 1960 a 1990.

\section{0 poeta surrealista subversivo}

A primeira recepção do que viria a ser Paranóia foi desconcertante. Ainda antes de sua publicação, o artista plástico Wesley Duke Lee, recém-chegado de uma temporada em Paris, leu os manuscritos da obra e saiu alucinado fotografando aquela nova cidade que se descortinava nos delírios de Roberto Piva. A estudiosa do artista plástico, Cacilda Teixeira da Costa, narra da seguinte forma a produção das fotos:

[Wesley] Passou sete meses percorrendo ruas, praças, becos, parques de diversão e o mundo homossexual de São Paulo em companhia do poeta [Roberto Piva], à procura de imagens. O que tentava encontrar era a imagem de um grito de Piva, a expressão visual do desespero do poeta com quem mergulhou no mundo-tabu da pederastia, aspecto da sexualidade que nunca havia enfrentado, mas que sempre o assustava. (Costa, 2005, p. 56-58)

Veja como Paranóia transfigura em Wesley uma outra experiência da cidade: seja a erotização de seus locais mais conhecidos, seja pela descoberta de novos espaços subversivos. Assim, a primeira recepção da obra levou à criação, criação que inclusive é parte importante do livro publicado com o ensaio fotográfico do artista.

Após o lançamento de Paranóia, Roberto Piva foi procurado por Sergio Lima - autor de Amore, publicado no mesmo período pela editora de Massao Ohno. Sergio Lima retornara de uma temporada de participação no surrealismo francês, ao lado de André Breton, e tinha o objetivo de formar uma sucursal do movimento no Brasil. Roberto Piva e seus amigos, por sua vez, acompanhavam instantaneamente as publicações francesas e tinham amplo conhecimento das obras e autores ligados ao surrealismo. Desse encontro, derivado da leitura de Paranóia, surgiu o "Grupo Surrealista de São Paulo", naquele mês de junho de 1963.

Além de Sergio Lima, Roberto Piva e Cláudio Willer, do grupo inicial participaram Antonio Fernando de Franceschi, Décio Bar, Roberto Rugiero, Regastein Rocha, Guilherme Faria e Ralph Camargo. Encontravam-se semanalmente num bar e realizavam leituras coletivas 
ou jogos surrealistas - como o cadáver esquix, em que os participantes escreviam versos sucessivamente ao acaso, resultando em combinações das mais inusitadas. Havia pequenos delitos, como pegar uma bebida de um mercado e sair sem pagar: atos considerados surrealistas por excelência.

Havia também atentados. Na tarde de 28 de setembro de 1963, o grupo fulminou alguns “necrológios", explosiva invenção de Cláudio Willer. Era a abertura da sétima edição da Bienal de São Paulo e foram distribuídos panfletos que comunicavam o "passamento" de artistas com os quais o grupo divergia. As atividades do grupo foram intensas e duraram alguns meses. No início de 1964, o grupo estava dissolvido. Por quê? Para Piva não havia grupo surrealista: eles saíam, bebiam e liam como sempre fizeram. Para Sergio Lima, no entanto, a dispersão se deu por divergência: o grupo trazia outras discussões relacionadas à geração beat ou manifestações contemporâneas que estavam, em sua opinião, distantes da "perspectiva surrealista" e de sua “atuação específica” (Lima, 2002). Claramente, Sergio Lima queria um grupo que discutisse especificamente o surrealismo de forma sistemática, proposta muito distante da turma anárquica e dispersiva de Roberto Piva e cia. Mas essa já é uma outra história.

A contrapartida dessa calorosa recepção de Paranóia por Wesley Duke Lee e Sergio Lima foi a frígida reação da crítica que, simplesmente, silenciou - numa época em que se dava grande destaque aos novos poetas. O silêncio pode ser visto como espanto, pois a verborragia

e audácia do livro criaram grande ruptura com a produção literária brasileira até aquele momento. Mas também calou-se por preconceito. Thomaz Souto Corrêa, jornalista ligado à crítica literária do período, é direto: jamais dariam espaço na imprensa para um livro lançado no meio dos vagabundos do Teatro Oficina, por um rapaz homossexual (Hungria; D'Elia, 2011). Mas se o silêncio preponderou nos meios públicos de comunicação, no ambiente privado muito se cochichou. Ali se falou pelos cotovelos, no velho ti-ti-ti do chá das cinco. Durante um jantar, Emy, esposa de Paulo Bonfim, comenta com Willer quão estarrecida ficou com a linguagem baixa do livro que insultaria o linguajar poético: "Willer, você é inteligente, como é que você admite uma coisa dessas, esses palavrões na poesia?” (Hungria; D’Elia, 2011, p. 60).

A subversão na vida e na poesia dificultaram a recepção pelos meios conservadores. Porém, se a crítica literária brasileira se calou, os ecos de Paranóia foram ouvidos na explosiva revista venezuelana El techo de la ballena, pelas mãos de Juan Calzadilla, e nada menos que a revista oficial do surrealismo francês La brèche: action surréaliste. Fiquemos com o texto "O surrealismo em São Paulo", publicado na edição de novembro de 1965 desta última. Considerando que "as correntes artísticas e intelectuais mantêm estreita relação com as estruturas econômicas e sociais" (La Brèche, 1965, p. 126), o texto apresenta uma 
contextualização política do Brasil, de Vargas ao golpe militar. Posteriormente, dedica-se a dados da aventura surrealista no país, com acento às estadias de Benjamin Péret em São Paulo e Rio de Janeiro, bem como a interlocução entre Murilo Mendes e Francis Picabia. Contudo, salvo estes "casos isolados", aponta-se a predominância de um "academicismo" flagrante nos meios artísticos brasileiros, do qual decorre uma "sabotagem intelectual" ao surrealismo, movida por "organismos oficiais, historiadores e críticos de arte" (p. 127). Tal conjuntura faz com que o surrealismo seja reivindicado por "espíritos mais subversivos". Dentre eles, o texto destaca Roberto Piva (com Paranóia) Sergio Lima (com Amore) e Claudio Willer (com Anotações para um Apocalipse) como "a primeira vez que o Brasil dispõe de obras em que os autores reclamam abertamente pelo surrealismo" (p. 127). Assim, as três obras são resenhadas brevemente, a exemplo de Paranóia:

Paranóia é o primeiro livro de poesia delirante publicado no Brasil. Piva, cuja formação intelectual é profundamente marcada pela cultura italiana, inspira-se nos grandes clássicos da decadência, de onde provém a exuberância de imagens própria dos povos latinos. Freud e Lautreamont têm para ele grande importância. Enfim, a mais moderna literatura beat norteamericana lhe transmitiu a fascinação dos neons e a alucinação pela metrópole metálica evocada pelas fotografias de São Paulo inseridas e seu livro. (La Brèche, 1965, p. 127).

O texto ainda afirma o "silêncio" da crítica literária e mesmo uma suspeita retirada destas obras das vitrines das livrarias. Por fim, fala de certa tentativa de organização de poetas e pintores em "grupo", muito embora tal atividade seja dificultada pelo contexto ditatorial.

A curta aventura do Grupo Surrealista de São Paulo parece ser essa tentativa de organização grupal, feita por poetas que abertamente reivindicaram pelo surrealismo no Brasil. Daí Roberto Piva ser um dos únicos poetas brasileiros a constar no Dicionário Geral do Surrealismo, publicado na França em 1982. Daí a recepção da poesia de Piva estar muito associada na década de 1960 ao seu viés surrealista, especialmente aquele da poesia como um modo de vida subversivo. Daí ser uma poesia que encontrará caminhos alternativos de divulgação, distantes da grande mídia e dos órgãos literários de maior repercussão pública.

\section{De poeta "marginal" a "poeta homossexual-proletário"}

Após a publicação de Piazzas, de Roberto Piva, e Anotações para um Apocalipse, de Claudio Willer, em 1964, Massao Ohno interrompe o grande ciclo de lançamento de novos poetas. O próprio editor menciona quão visado estava sendo pela censura e temia represálias. Não é por menos, ambas as obras denunciam de forma audaz as práticas de torturas em instituições governamentais nos primeiros descalabros da ditadura brasileira. Deriva desse 
clima de censura um recesso nas publicações literárias que explica este primeiro grande intervalo na publicação de Piva - cujo próximo livro sairia apenas em 1976. Aliás, aceita-se com muita facilidade a ideia de que Roberto Piva produzia por "surtos" - como afirma Alcir Pécora (2005, p. 9). Tal ideia negligencia as intempéries do contexto político e literário da época, que se impunham aos intempestivos surtos do poeta. Veremos quanto a produção de Roberto Piva foi constante e ininterrupta. Contudo, a comunicação com o grande público não dependia da vontade do poeta, mas do sistema literário que, como na época de ditadura, não oferecia oportunidades de publicação a criações extremamente subversivas.

No início da década de 1970, a produção poética de Roberto Piva encontra público nos meios ligados à juventude roqueira. Em seus textos publicados na revista Artes:, o poeta faz as vezes de crítico literário, entrevistador e agitador cultural, versando também sobre uma variedade de matérias (artes plásticas, música e literatura). Como profeta do rock, redigiu materiais de afirmação de suma importância histórica para a juventude, em um contexto em que ainda se questionava a legitimidade artística da música pop no Brasil. Como poeta, publica o importante poema “Onde estará você agora, enquanto nuvens lançam sombras loucas sôbre estas mesas \& lindos rostos pagãos me observam viver?". Vejamos um trecho do poema:

(...) um deus acaba de nascer numa fôlha de plátano trazida pelo vento / os telefones do mundo começam transmitir mensagens eróticas / as janelas explodem em sinfonia o mundo é um maravilhoso lugar para se nascer / o espaço é esplêndido / eu vejo / eu acredito como Whitman no corpo \& nos seus apetites / eu sinto a vida nos intestinos / eu tenho muitas verdades dentro do meu coração de carne / há um girassol abandonado nos teus olhos, Paulo? Que correnteza nos levará à deriva hoje? Sandwiches / ostras / latas de cerveja / enxurrada maravilhosa saída da guitarra de Johnny Winter numa tarde de sol de fevereiro em São Paulo! (Piva, 1972, p. 3).

O poema retrata o entusiasmo diante da cena musical jovem, com fortes rompantes beats e diálogos com Walt Whitman e Allen Ginsberg. Este último comparece implícito em "sandwiches" e girassóis, e explicitamente na interrogação: "Que correnteza nos levará à deriva hoje?", similar a “Aonde vamos, Walt Whitman? [...] Que caminhos aponta tua barba esta noite?", verso de Um Supermercado da Califórnia (Ginsberg, 1956/2005, p. 49). O mesmo intertexto já estava presente na Ode a Fernando Pessoa de Roberto Piva ("Fernando Pessoa, Grande Mestre, em que direção aponta tua loucura esta noite?” - Piva, 1961/2005, p. 21) ou em Paranóia, referindo-se a Mário de Andrade ("Que novo pensamento, que sonho sai de tua fronte noturna?" - Piva, 1963/2005, p. 64). A proximidade com a contracultura beat fica evidente também no final do poema, em menções pioneiras à poesia corporal de Michael McClure - com o qual se corresponderia nessa mesma década.

De forma clandestina e underground, Roberto Piva atinge grande penetração nos meios jovens ligados à contracultura, como entre os leitores de fanzines alternativos - como a revista 
Patata - na qual o poeta colabora no ano de 1973. Por essas vias subterrâneas, a poesia de Roberto Piva encontrou grande recepção entre os jovens subversivos do que se convencionou denominar como "poesia marginal".

Com poemas de seu livro Paranóia, o poeta paira como presença estranha na antologia 26 poetas hoje (1976), cujo material foi selecionado por Heloisa Buarque de Hollanda, Chico Alvim e Cacaso. Isto porque Roberto Piva não compunha o grande movimento artístico em torno da Nuvem Cigana, tampouco comparece com materiais daquela década de 1970. É obscuro o motivo da participação de Piva na antologia. Da perspectiva política, o argumento de Heloisa é de que tais poetas constituem vozes dissonantes no contexto repressivo da ditadura como "filhos da ditadura" ou "geração AI5" (Hollanda, 2007, p. 261). Não é o caso de Roberto Piva, poeta pertencente aos Novíssimos de 1960, cuja produção de Paranóia responde a um contexto histórico anterior à ditadura - muito embora também denuncie, a seu modo, os policiamentos morais e afirme a via transgressora. Sob o aspecto literário, não há qualquer confluência da dicção poética de Paranóia com seus volteios surreais com aquela busca de poetas marginais por um coloquialismo típico do modernismo brasileiro - especialmente o instantaneísmo oswaldiano. Assim, não havendo diálogo de movimento artístico, literário e político, qual o motivo da participação de Roberto Piva na antologia?

Chacal é certeiro: "Piva era o único que trazia um comportamento transgressor" (Cohn, 2007, p. 102). É na poesia como modo de vida subversivo que tais poéticas se identificam. O que Roberto Piva chamou de poesia experimental amalgamada à vida experimental, ou aquilo que Heloisa Buarque de Hollanda coloca como ponto comum entre os "marginais": a “elaboração literária da matéria vivenciada” (1975/2007, p. 11).

A opinião de Franchetti (1997, p. 286) é emblemática: Roberto Piva foi assimilado à “poesia marginal” por não se enquadrar em nenhuma das correntes literárias da década de 1960 ("concretos", "poesia politicamente comprometida" ou o "beletrismo neoparnasioano"). Por contraditório que pareça, a inclusão entre os "marginais" foi forma de tirá-lo da marginalização. Piva recusa o rótulo, mas reconhece a importância da boa recepção entre poetas jovens da geração seguinte que tinham uma vida poética potente.

E lá estava Roberto Piva no Parque Lage, no dia 14 de julho de 1976, para o lançamento da antologia. O vídeo "Noite Acesa", de Luiz Alphonsus (1976), dá movimento ao que foi aquela noite. Uma juventude alucinada ao som de guitarras distorcidas e uma névoa de fumaça de estranhos cigarros. No vídeo, Piva faz uma aparição chistosa: nitidamente inebriado, sobe ao palco atrapalhado procurando onde havia deixado os poemas para sua leitura. 
O fato é que o rótulo de Piva como poeta marginal se impõe a partir de meados de 1970 e permanece em alguns meios até hoje - a julgar pela divulgação do evento "Epivanias", em que Gabriel Fabri (2013) apresenta o poeta como "um dos mais expressivos nomes da poesia marginal no Brasil".

Quanto à recusa da designação, a questão de Piva não é com os poetas marginais, mas com a crítica literária. Piva leva uma vida que pode bem ser compreendida como marginal. Mas o poeta salienta quão marginalizado foi - referindo-se ao boicote da crítica. Assim, afirma que não é poeta "marginal", mas "marginalizado": "Eu não me marginalizei. Fui marginalizado" (A voz da transgressão, 2005).

De novo em vórtice paradoxal, a relação entre Roberto Piva e o movimento carioca aponta como Piva foi "marginalizado" entre os marginais. Salta aos olhos, por exemplo, o espaço da poesia de Piva na "Escrita Revista Mensal de Literatura", em comparação aos marginais. No número 11 da revista, de abril de 1976, publica-se o poema “O coração absoluto em canteiros \& navalhas", de Roberto Piva em parceria com Henrique Carneiro. O poema consta na seção de "Novos: poemas", ou seja, na parte da revista dedicada a novos poetas! Roberto Piva é apresentado como "paulista de Brotas" - talvez porque a linha editorial quisesse ressaltar seu incentivo a criações do interior do estado. Esta posição marginal de Roberto Piva contrasta com o grande destaque dado à vinda dos poetas marginais cariocas na capa da edição de abril de 1977: “A vez dos marginais”. Na longa entrevista, Roberto Piva sequer é mencionado. O poeta não tem vez entre os marginais.

$\mathrm{O}$ fato é que o grande furor em torno dos marginais reacendeu o mercado editorial e Massao Ohno retomou sua atividade a pleno vapor. O número de publicações foi tão grande que ele convidou Claudio Willer para organizar um lançamento coletivo que, insuflado com os ventos da juventude açoitada pela repressão militar, tomou o vulto da Feira de Poesia - evento com grande significado político nas manifestações pela redemocratização do país. Na Feira, Roberto Piva lança seu Abra os Olhos e Diga Ah!, obra que reflete uma forte guinada política em sua criação poética. A expressão "política do corpo em chamas" (Piva, 1976/2006, p. 28) aponta o centro da política contemporânea no corpo, seja aquele crivado de balas pela repressão ou ardendo nas chamas do amor, em resistência erótica à sociedade disciplinar.

A repercussão da Feira de Poesia foi tão grande que Claudio Willer continuou seu ímpeto na organização de recitais, juntamente com Ruth Escobar, sobre poetas revolucionários (como Pablo Neruda) ou vítimas de estados totalitários (como Garcia Lorca). Nesses recitais, Roberto Piva lia poema dedicado "aos presos políticos do Brasil. Contra a tortura, pelas 
liberdades democráticas" (Piva, 1978a, p. 36). Em diálogo (dissidente, por sinal) com meios ligados à esquerda, o poeta encontra público entre os cidadãos em luta por direitos sociais.

A convite de Willer, editor de sua seção de poesia, Roberto Piva contribui no revolucionário "Versus - jornal de política, cultura e idéias", durante o ano de 1978 - e depois, em continuidade a sua coluna Meditações de Emergência, à revista Singular \& Plural. Em suas páginas, Roberto Piva produz poemas com temas e vocabulário típicos da esquerda, ao que o próprio Claudio Willer denominou como "poesia social” (1978, p. 37). Em “O Mississipi no Amazonas", por exemplo:

(...) gostaria de ver aquela tribo maravilhosa de adolescentes proletários se dependurarem nos cipós do Ocidente \& aterrorizarem nos salões de banquetes como Tarzans enquanto o BurguêsInseto recolhe as asas \& faz cocô branco de susto-Impotência \& úlceras pépticas na cristalização de química imperfeita-purgatório-fêmea \& bicha de boite (Piva, 1978b, p. 30).

Com o termo "proletário", Piva introduz expressão conceitual típica dos marxismos. Esses adolescentes surgem como força ativa da transformação social - numa figura ao mesmo tempo erótica e selvagem, o Tarzan - em contradição com a burguesia como classe social conservadora (simbolizada pelo público homossexual frequentador de casas noturnas especializadas). A atividade de uns e a passividade de outros responde ao espectro político e à posição na cama, em uma junção entre o erótico e o político. Com as expressões "proletário" e "burguês" figurando uma luta de classes, estaria Roberto Piva lançando mão de uma visão dialética da história?

Além do público da Versus, a poesia de Roberto Piva teve grande penetração nos meios revolucionários jovens, especialmente na Libelu (Liberdade e Luta) - grupo trotskista atuante no movimento estudantil e ligado à Organização Socialista Internacionalista. Ali, Roberto Piva era poeta reconhecido e considerado ativista da área cultural. Dessa recepção na Libelu derivou a publicação da segunda edição de Piazzas, em 1981, pela Kairós - editora do movimento, com coleções voltadas ao pensamento socialista (em especial de Trotsky).

Naquele mesmo ano de 1978, o poeta teve ainda poemas publicados no número inaugural da Caderneta de Poesia, da combativa editora Brasiliense - número em "homenagem aos movimentos de libertação nacional dos povos da Guiné-Bissau e Cabo Verde, São Tomé e Príncipe, Angola e Moçambique".

Porém, foi no interior do movimento de luta pelos direitos sexuais que Roberto Piva teve maior repercussão. No órgão gay Lampião da Esquina, a obra recém-publicada do poeta (Coxas, 1979) é divulgada insistentemente nas edições do jornal como "o melhor exemplo da nossa poesia" (jornal O Lampião da Esquina, 1979). Não é para menos, Coxas começa com a 
descrição de sexo entre garotos no Alto do Copan: "O adolescente ajoelhou-se abriu a braguilha da calça de Pólen \& começou a chupar" (Piva, 1979, s/p). A obra recebe ainda resenha de Glauco Mattoso (1978), salientando o tom homoerótico do poeta maldito ligado à contracultura.

Com o próprio Glauco Mattoso, além de João Silvério Trevisan, Roberto Piva participou de uma mesa de debates sobre o movimento gay - no dia 8 de fevereiro de 1979, na Universidade de São Paulo, na semana das chamadas "minorias". Roberto Piva é apresentado como "poeta homossexual-proletário" e toma a palavra para dizer que nos países do "bloco socialista" - como Cuba, Moçambique e Leste Europeu - há grande "liberdade sexual" (Dantas, 1979).

O poeta roqueiro, que inicia a década divulgando suas produções em meios juvenis de música pop, passa a ser vinculado ao movimento da poesia marginal e finda o período flertando com os meios de esquerda como "poeta homossexual-proletário".

\section{3 "O maior poeta brasileiro da atualidade"}

A atividade política de Roberto Piva teve ainda ressonâncias no nascente ativismo ambientalista brasileiro, em torno do Movimento Arte e Pensamento Ecológico. Fortemente marcado pela interface entre ecologia e estética - como as performances impactantes de Miguel Abellá -, o movimento publicou em seu boletim diversos manifestos de Roberto Piva, desde 1983. Materiais como "Manifesto da selva mais próxima" ou "Manifesto utópico-ecológico em defesa da poesia \& do delírio" dão conta dessa pegada que atrela o ecológico ao poético e ao selvático. Este último é iniciado da seguinte maneira: "Eu defendo o direito de todo ser Humano ao Pão \& à Poesia. Estamos sendo destruídos em nosso núcleo biológico, nosso espaço vital \& dos animais está reduzido a proporções ínfimas” (Piva, 1983, p. 12). No vórtice de sua poética, se emaranham a esfera estética e uma utopia enfatizada em termos ecológicos.

Outro desses manifestos, o fulgurante “O século XXI me dará razão (se tudo não explodir antes)", foi publicado ineditamente na principal recepção da poesia de Roberto Piva durante a década de 1980: o ambiente beat e anárquico da editora L\&PM. Em meio à Coleção Rebeldes \& Malditos (que trouxe autores como Baudelaire, Rimbaud e Artaud), ou a "Alma Beat" (com Kerouac, Ginsberg, Corso e cia.), Eduardo Bueno (Peninha) convida alguns "malucos" para lançar uma coleção de rebeldes à moda da casa: os "livros marginais" que compuseram a Coleção Olho da Rua (L\&PM, 2011). Nesta coleção, Roberto Piva tem sua primeira antologia de poemas publicada de forma entusiasmada por mais uma nova geração de grandes poetas, tradutores e editores. 
O Roberto Piva dessa metade da década de 1980 é aquele mesmo que abandonou todas as esperanças revolucionárias da década de 1970: “eu abandonei o passado a esperança / a memória o vazio da década de 70 / sou um navio lançado ao / alto-mar das futuras / combinações" (Piva, 1981/2006, p. 115). No mesmo 20 poemas com brócoli, o poeta aponta onde sua deriva em alto-mar o levou: "fazer da anarquia um método \& modo de vida" (p. 111). Os poemas da antologia são também dedicados à "Anarquia" e contam com a inspirada apresentação dos editores, intitulada "O profeta da desordem" (L\&PM, 1985). Nela, Roberto Piva surge como personagem anárquico (em "permanente insurreição contra todas as Ordens"), subversivo ("prisões, com o desemprego permanente, LSD e cogumelos sagrados, jazz \& rock, paixão, delírios e garotos") e levando uma vida experimental com sua poética "maldita, conturbada". Pela primeira vez, Roberto Piva tem reconhecidas as rupturas de sua linguagem poética dentro do contexto literário nacional: "Na verdade antes dele ninguém ousava escrever poesia dessa forma no Brasil. Ninguém rompera tão radicalmente com a escritura acadêmica e cerebral". Por fim, de maneira triunfante, Roberto Piva é aclamado como "o mais indômito, o mais rebelde e um dos mais inspirados poetas brasileiros das últimas décadas".

Falta ainda a valorização da importância axial dessa antologia no reconhecimento da poesia de Roberto Piva. Seja pela reunião de materiais feita pelo próprio poeta, seja pela crítica consistente que apresenta, a antologia é dos principais cartões de visita de Roberto Piva. Sua publicação proliferou a poesia de Piva pelos meios libertários e abriu novas picadas para sua poética selvagem.

Com a resenha de Régis Bonvicino (“O boêmio Piva não tem papas na língua”, 1985) já há uma crítica ao equívoco da inclusão de Piva na "Poesia Marginal", além da afirmação de seu viés "beat/surrealista" com inserção exaltada no interior da literatura nacional: “...parece dizer que veio para reinaugurar a utopia da própria poesia. Da poesia libertadora, que sai do papel para ter existência real no dia-a-dia humano". Com a entrevista a Carlos von Schmidt (1985) há comentários fundamentais de Piva sobre toda sua obra poética. Com a aproximação de Floriano Martins, abrem-se as brechas para o papel de Piva no interior das manifestações surrealistas na América Latina.

E foi exatamente um poeta latino-americano quem ajudou a disseminar poesia de Roberto Piva em outros países do continente. No exemplar autografado a Nestor Perlongher, Piva escreve: "Para o Nestor, com o abraço anárquico \& antológico do Roberto Piva. Irmão em Universo". O adjetivo antológico diz um pouco sobre a importância da publicação para o poeta. $\mathrm{O}$ virulento anarquista argentino também daria grande importância à poesia de Piva, em especial no tratamento transgressor da sexualidade. Perlongher vivia no Brasil desde 1982 e dava aqui 
prosseguimento à sua aguerrida militância nos movimentos homossexuais, com sua pesquisa sobre os michês. Por intermédio desse poeta e de outros mais, a antologia levaria a poesia de Piva para publicações alternativas argentinas, como o caso da mitológica revista Cerdos \& Peces.

Além do manifesto anárquico e libertino O Erotismo dará o golpe de estado (1987), ou da entrevista $O$ agitador da transgressão (1987), basta dizer que Roberto Piva é apresentado na revista argentina como “el mayor poeta brasileño de la actualidad”! (Piva, 1989b).

No mesmo período da Cerdos \& Peces, Roberto Piva também ganha grande projeção nacional em suas contribuições na Revista Chiclete com Banana - ao lado do mesmo Angeli com o qual publicara na Revista Patata. Angeli e Toninho Mendes seriam outros artistas jovens influenciados por Piva, uma vez que consideravam a presença do poeta como "um verniz intelectual à revista” (Hungria; D’Elia, 2011, p. 159).

Em sua estreia na revista, na edição 15 , republica-se, como editorial, o manifesto " $\mathrm{O}$ século XXI me dará razão (se tudo não explodir antes)”. A perspectiva ecológica é marcante, inclusive no título da seção ("Sindicato da Natureza"), assumindo mesmo feições panfletárias. Na edição de número 19, de 1989, o texto de Roberto Piva começa da seguinte maneira: “Temos de ter sempre presente na memória: Na fase avançada da produção em massa, uma sociedade produz a sua própria destruição". O poeta está irreconhecível: adota uma linguagem discursiva (sem imagens ou cores) e um tom programático, com receituários do comportamento ecologicamente correto.

Ainda na década de 1980, pode-se mencionar a participação de Roberto Piva no filme Heróis da decadensia (1987), do jovem cineasta Tadeu Jungle. O poeta surge bebendo cerveja na Serra da Cantareira, falando em orgias e LSD, além de esbravejar blasfêmias contra o cristianismo. Tais cenas são entrecortadas com falas de Dom Paulo Evaristo Arns, reforçando a presença do poeta "herói" como o próprio anticristo.

Neste mesmo ano de 1987, Roberto Piva publica seus primeiros poemas xamânicos ("VII cantos xamânicos") em mais uma boa recepção de sua poesia em veículos ousados: o jornal Verve, editado no Rio de Janeiro por Claudia Roquette-Pinto. É um período em que a poesia de Piva também encontra ressonâncias em poetas como Rodrigo Garcia Lopes, com o qual mantém relações amistosas a partir do interesse de ambos em poetas beat estadunidenses.

Assim, durante a década de 1980, a poesia de Roberto Piva expande suas fronteiras para todo o país (com a L\&PM ou Chiclete com Banana) e mesmo para a América Latina. A recepção de sua poesia ganha um tom crítico de reconhecimento da produção do poeta no 
âmbito da literatura nacional. Por influência dos próprios temas de sua poesia, Roberto Piva passa a ser vinculado à Ecologia e à Anarquia.

\section{0 xamã}

Após a boa maré de 1980, a recepção da poesia de Roberto Piva entra em refluxo no início dos anos 1990. Desde 1982, o poeta acumulava poemas de suas experiências mágicas nas matas do interior do estado de São Paulo. Nas entrevistas concedidas a Ademir Assunção e Miguel de Almeida, em 1991 e 1993, respectivamente, o poeta menciona a existência de um livro pronto, Ciclones, que aguardava oportunidade de publicação.

No dia 21 de fevereiro de 1994, Roberto Piva recebe o pesquisador Claudio Roberto da Silva em seu apartamento. O historiador desenvolvia um estudo sobre a atuação política do movimento homossexual, a partir da narrativa de histórias de vida de alguns ativistas. Entre eles, o poeta foi escolhido por suas colaborações no Lampião da Esquina. Roberto Piva desabafa:

Prefiro viver os poemas do que escrevê-los... porque dá muito trabalho. Eu não sei escrever à máquina e preciso chamar alguém que fica três horas para bater os poemas. Tenho uma máquina quebrada e não tenho dinheiro para mandar consertar, assim ficam elas por elas. Estou com dois livros parados por causa desses problemas... (Silva, 1998, p. 319-320).

A poesia de Roberto Piva, porém, constava em breve antologia do anarquista Edson Passetti, em Das fumeries ao narcotráfico (1991), como exemplos de expressões artísticas sob efeito de alucinógenos. Este mesmo livro foi lido por jovens rebeldes como Sergio Cohn, que correu a cidade à procura de Paranóia. Numa noite de setembro de 1993, os jovens poetas criadores da revista Azougue encontram pessoalmente com Roberto Piva, iniciando com ele profunda amizade.

Nos vários depoimentos de Sergio Cohn, especialmente no livro Roberto Piva, publicado na coleção Ciranda de Poesia (2012), pode-se observar a importância do autor de Paranóia na formação dessa nova geração de poetas e editores. Nas longas tardes que passavam juntos, Roberto Piva lia e traduzia simultaneamente uma variedade de poetas franceses e italianos, além de comentar detalhadamente obras como Invenção de Orfeu, de Jorge de Lima. Sergio Cohn chega a comparar essas tardes com uma formação superior, uma "escola". E o mestre Roberto Piva lia e comentava os poemas de Cohn, Danilo Monteiro e cia., chegando mesmo a mencionar seu entusiasmo em organizar uma antologia da poesia jovem, com o nome emprestado de Pasolini: “A Voz Violenta da Novíssima Poesia Brasileira” (Cohn, 1996). 
As relações entre este encontro com Roberto Piva e a revista Azougue já foi tema de pesquisa científica (Berlanda, 2011). Foi a principal recepção da poesia desse xamã durante a

década de 1990. No ano de 1996, a revista traz um especial com Roberto Piva com ampla antologia e materiais inéditos - como o "Manifesto da poesia xamânica \& bio-alquímica". Foi por intermédio dessa publicação que Roberto Piva finalmente encontrou editora para sua obra Ciclones, a partir de seu impacto em outro importante poeta contemporâneo, Fabio Weintraub. Os meandros da organização do material para o livro são elucidativos. Sergio Cohn os digitou com Roberto Piva e participou mesmo da seleção de materiais e concepção do livro. A constatação foi drástica: o amplo material - que havia crescido muito desde a primeira menção à obra então concluída, na entrevista de 1991 a Ademir Assunção - daria para três livros distintos. No entanto, temendo não haver outra oportunidade de publicação, Roberto Piva decide uni-los no mesmo livro.

Aos toques do tambor mágico e cercado por jovens criativos, o poeta se afirma como xamã, seja na performance na Funarte (1996), ainda antes da publicação de Ciclones, seja nos recitais para a divulgação do livro. As participações de Roberto Piva na Poesia Sempre - revista semestral de poesia, em meados de 1997, selam o reconhecimento de sua poesia.

Ao final desta mesma década, Roberto Piva escreveria textos no lançamento do livro do amigo Zé Celso (Zé Celso - Primeiro Ato, 1998) ou de Glauco Mattoso (na orelha de Geléia Rococó - sonetos barrocos, 1999).

São os momentos que antecedem o estouro em torno da reedição de Paranóia, em 2000, cujos efeitos ainda se fazer sentir na multiplicação de pesquisas científicas, ensaios críticos, documentários cinematográficos, materiais inéditos e depoimentos disseminados na Internet.

Em síntese, o breve sobrevoo na recepção da obra poética de Roberto Piva observou o acento da década de 1960 em sua relação com a aventura surrealista. Na década de 1970, foi ressaltada sua retomada pela juventude da contracultura, especialmente pela "poesia marginal" carioca. Os contornos políticos mais evidenciados em sua produção poética redundaram na recepção por meios revolucionários e de luta por direitos sociais no final de 1970 (especialmente nos movimentos gay e ecológico). Na década de 1980, a poesia de Piva irradiou para diversas direções, com acento na antologia da editora L\&PM e nas revistas Chiclete com Banana e Cerdos \& Peces. Após breve refluxo, os meados da década de 1990 viram o impacto da poesia de Roberto Piva em mais uma nova geração de poetas (azougueiros), além da afirmação de sua poesia xamânica. 


\section{Referências}

A voz da transgressão. Entrevista concedida à Revista Época. 2005. Disponível em: http://revistaepoca.globo.com/Revista/Epoca/0,„EDG72087-6011-389,00.html. Acesso em: 16 out 2006.

ALMEIDA, Miguel. Epifanias do erotismo sagrado. (Entrevista). Em: COHN, Sérgio (org.). Roberto Piva (Coleção Encontros). Rio de Janeiro: Azougue, 1993/2009. pp. 104-109.

ALPHONSUS, Luiz. Noite Acesa. 1976. Super-8.

ASSUNÇÃO, Ademir. A poesia selvagem e de possessão de Roberto Piva. (Entrevista). Em: COHN, Sérgio (org.). Roberto Piva (Coleção Encontros). Rio de Janeiro: Azougue, 1991/2009. pp. 96-103.

BERLANDA, Ibriela Bianca. A revista Azougue e o poeta Roberto Piva: o saque e a dádiva. 2011. 284 fs. Dissertação (Mestrado em Literatura) - Universidade Federal de Santa Catarina, Florianópolis, 2011.

BONVICINO, Régis. O boêmio Piva não tem papas na língua. Folha de São Paulo, 02.06.1985.

COSTA, Cacilda Teixeira da. Wesley Duke Lee: um salmão na corrente taciturna. São Paulo: Alameda Edusp, 2005. 212 p.

COHN, Sergio. O capitão loucura. Folha de São Paulo, 1996. Disponível em: http://www1.folha.uol.com.br/fsp/ilustrissima/il2006201008.htm. Acesso em: 03 fev 2013.

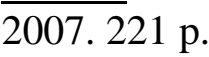

Nuvem Cigana: poesia e delírio no Rio dos anos 70. Rio de Janeiro: Beco do Azougue, . Roberto Piva. Rio de Janeiro: EdUERJ, 2012. 81 p. (Coleção Ciranda da Poesia).

DANTAS, Eduardo. Negros, mulheres, homossexuais e índios nos debates da USP. Jornal Lampião da Esquina, Ano 1, n. 10, março de 1979, p. 09

FABRI, Gabriel. Evento promove imersão ao imaginário de Roberto Piva. Em Cartaz, n. 72, outubro de 2013, pp. 55.

FRANCHETTI, Paulo. Estudos de literatura brasileira e portuguesa. Cotia: Ateliê editorial, 2007. p. 293.

GINSBERG, Allen. Uivo e outros poemas. Em: GINSBERG, Allen. Uivo, Kaddish e outros poemas. (Claudio Willer, trad.). Porto Alegre: L\&PM, 1956/2005. pp. 19-65 (Coleção LP\&M Pocket, vol. 188).

Heróis da decadensia. Direção de Tadeu Jungle e Walter Silveira. 1987.

HOLLANDA, Heloisa Buarque de. Apresentação. Em: 26 poetas hoje. $6^{\mathrm{a}}$ ed. Rio de Janeiro: Aeroplano, 1975/2007. pp. 09-14. 
256-263.

Posfácio. Em: 26 poetas hoje. $6^{\mathrm{a}}$ ed. Rio de Janeiro: Aeroplano, 2007. pp.

HUNGRIA, Camila; D’ELIA, Renata. Os dentes da memória: Piva, Willer, Franceschi, Bicelli e uma trajetória paulista de poesia. Rio de Janeiro: Beco do Azougue, 2011. 255 p.

Jornal Lampião da Esquina. Ano 2, n. 15, agosto de 1979, p. 17.

La Brèche: action surréaliste. n. 8, novembro de 1965. Disponível em: http://melusine.univparis3.fr/LaBreche/La_Breche_8.htm. Acesso em: 09 jan 2011.

L\&PM. O profeta da desordem. Em: PIVA, Roberto. Antologia poética. Porto Alegre: L\&PM 1985.

L\&PM. Era uma vez... uma editora. 2011. Disponível em: http://www.lpmblog.com.br/?tag=colecao-olho-da-rua. Acesso em: 22 dez 2012.

LIMA, Sergio. Notas acerca do movimento surrealista no Brasil (da década de 20 aos dias de hoje). 2002. Disponível em: http://www.triplov.com/surreal/sergio_lima.html . Acesso em: 04 jul 2010.

MATTOSO, Glauco. O poeta das coxas. Jornal Lampião da Esquina, Ano II, n. 16, setembro 1979, p. 17.

PASSETTI, Edson. Das fumeries ao narcotráfico. São Paulo: EDUC, 1991. 154 p.

PÉCORA, Alcir. Nota do organizador. Em: PIVA, Roberto. Mala na mão \& asas pretas obras reunidas volume II (organização Alcir Pécora). São Paulo: Globo, 2006. pp. 09-18.

PIVA, Roberto. Ode a Fernando Pessoa. Em: PIVA, Roberto. Um estrangeiro na legião - obras reunidas volume I (organização Alcir Pécora). São Paulo: Globo, 1961/2005. pp. 18-25.

Paranóia. Em: PIVA, Roberto. Um estrangeiro na legião - obras reunidas volume I (organização Alcir Pécora). São Paulo: Globo, 1963/2005. pp. 26-73.

Onde estará você agora, enquanto nuvens lançam sombras loucas sôbre estas mesas \& lindos rostos pagãos me observam viver?. Revista Artes:, São Paulo, Ano VII, n. 35, 1972, p. 3.

. Abra os olhos e diga Ah!. Em: . Mala na mão \& asas pretas - obras reunidas volume II (organização Alcir Pécora). São Paulo: Globo, 1976/2006. pp. $22-45$.

. O hino do futuro é paradisíaco. Versus - um jornal de política, cultura e idéias, n. 23, julho/agosto, 1978a, p. 36.

. O Mississipi no Amazonas. Versus - um jornal de política, cultura e idéias, n. 20, abril/maio, p. 30, $1978 \mathrm{~b}$.

. Coxas: sex fiction \& delírios. São Paulo: Feira de Poesia, 1979. 
20 poemas com brócoli. Em: . Mala na mão \& asas pretas - obras reunidas volume II (organização Alcir Pécora). São Paulo: Globo, 1981/2006. pp. 92-117.

Manifesto utópico-ecológico em defesa da poesia \& do delírio. Boletim Arte e Pensamento Ecológico, n. 18, março 1983, pp. 12-13.

. Sindicato da Natureza. Chiclete com Banana, n. 19, julho 1989a, p. 26. . Animales Miserables. Cerdos \& Peces, n.19, 1989b, p. 27.

SILVA, Claudio Roberto da. Reinventando o sonho - história oral de vida política e homossexualidade no Brasil contemporâneo. 1998. 674fs. Dissertação (Mestrado em História Social) - Universidade de São Paulo, São Paulo, 1998.

VON SCHMIDT, Carlos. Amor, loucura, drogas (Entrevista). Em: COHN, Sérgio (org.). Roberto Piva (Coleção Encontros). Rio de Janeiro: Azougue, 1985/2009. pp. 54-69.

WILLER, Claudio. Uma introdução à leitura de Roberto Piva. Em: PIVA, Roberto. Um estrangeiro na legião - obras reunidas volume I (organização Alcir Pécora). São Paulo: Globo, 2005. pp. 144-185. 